\title{
Historein
}

Vol 14, No 1 (2014)

On the Edge of History and Philosophy

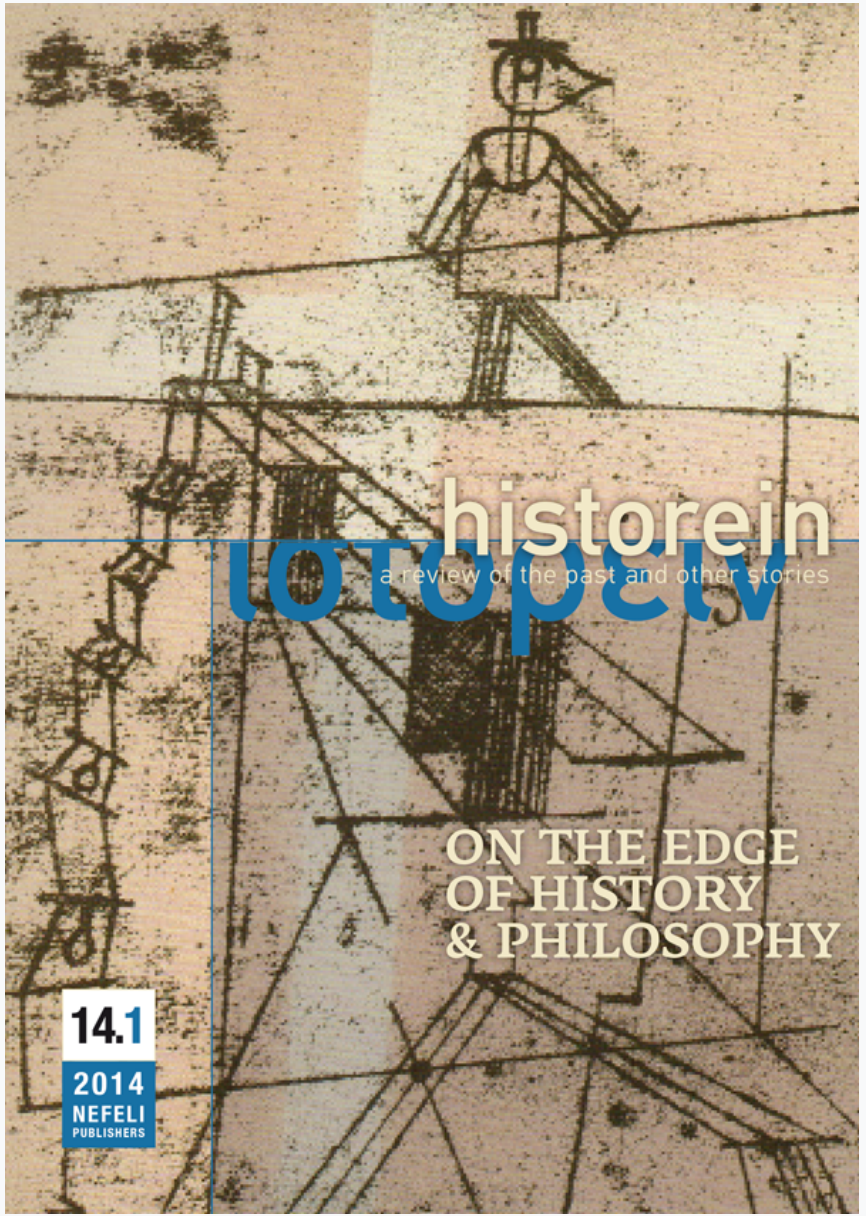

\section{About lost futures or the political heart of history}

María Inés Mudrovcic

doi: $10.12681 /$ historein.228

Copyright $\odot$ 2014, María Inés Mudrovcic

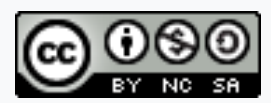

This work is licensed under a Creative Commons Attribution-NonCommercialShareAlike 4.0.

\section{To cite this article:}

Mudrovcic, M. I. (2013). About lost futures or the political heart of history. Historein, 14(1), 7-21. https://doi.org/10.12681/historein.228 
"Sólo le pido a Dios

Que el Futuro no me sea indiferente"

—León Gieco'

The consideration that our era lives under the sign of memory and that this has become the main concern of culture in western societies is a commonplace. This shift to the past has been described as a "memory boom", ${ }^{2}$ a "surfeit of memory", a "world (that is) being musealised"4 and as a "desire to commemorate". ${ }^{5}$ This "obsession with recalls" has been interpreted in many studies: on local, cultural or "from below" memories, on ways of keeping memories (from memorials and monuments to files, movies, biographies and commemorations, etc), on ways of understanding a historiography that looks back to the recent past, about politics of memory and past uses, among other issues. These studies have multiplied in the most varied disciplines, including, sociology, social psychology, history, psychoanalysis, neurobiology, culture sociology, philosophy, etc. The diagnosis seems to be unanimous: we are living in a period in which the present lives off the past, in a kind of "a present past", ${ }^{6}$ with the result that we lapse into what Hartog calls "presentism". This past that lives in the present has been called "traumatic", "sublime", " "espectral"," among others. We are experiencing a "new order of time": "D'un coté ... un passé qui n'est pas aboli ni oublié, mais un passé duquel ne pouvons à peu prés rien tirer qui nous oriente dans le present et nous donne à imaginer le future. De l'autre, un avenir sans la moindre figure."10 An order of time which casts doubts on the future understood as progress. It puts in question the modern regime of temporality; "instead of being oriented towards the future, it is oriented towards the past".

\section{About lost futures \\ or the political \\ heart of history}

\section{María Inés Mudrovcic}

National University of Comahue, Argentina

National Scientific and Technical Research Council, Argentina 
There would also be a coincidence when accepting that this curious fact of living submerged in the past comes from the dissolution of the future as it was expressed in the modern promise of progress, the catastrophes of the twentieth century being one of the causes of its destruction." These observations are found everywhere. However, few dare to make a diagnosis of this present trapped in the past. For many authors, the concept of trauma - both psychoanalytical and neurobiological - can be useful to understand the historicity of contemporary societies which were inherited from the tragic events of the recent past. ${ }^{12}$ However, in my opinion, this response involves two types of problems. Firstly, it assumes that there is a "normal" order of time opposed to a "pathological" (traumatic) one. Secondly, it ignores the relation that Koselleck, very carefully, establishes between the temporal order and the political one in early modernity. Indeed, the tragic events of the twentieth century aided in the destruction of modern temporality. A future perceived as progressive began to dissolve towards the end of the 1970s, and fully vanished by the 1980s. The question is: why is this a new order and not a different one?

This article attempts to show that in western societies today, in the absence of absolute foundations and the lack of a frame of meaning that opens new horizons of expectations, a political selfunderstanding of the present in terms of the past is beginning to emerge. This is possible because the major "catastrophes" of the twentieth century (the Holocaust, Latin American state terrorism, the Gulag, etc) have not established a rupture between past and present on the political plane. What I am trying to show here is that the kind of break between past and present made possible by events such as the French revolution and the fall of the Soviet Union took place because these events provoked political ruptures. Because the catastrophes of the twentieth century did not break the political order which gave birth to them (the modern secular state), they have created an order of time which, without leaving the future aside, feeds itself from the past which is read in the register of a memory code. A symptom, among others, of this new order of time would come in the creation, in legal terms, of the concept of "crimes against humanity".

In Sublime Historical Experience, Ankersmit describes four types of forgetting. In the first place, he recognises a daily type of forgetting which has no relevance to our present or future identity, for example, when we forget what we ate at dinner two days ago. A second type of forgetting is relevant to our identity, "but we were simply not aware of this". Sometimes we forget some details of our lives that psychoanalysis shows to be of significance for our personality. However, there are two others types of forgetting that Ankersmit calls trauma 1 and trauma $2 .{ }^{13}$ The two decades of silence that followed the Nazi period in Germany after the second world war are, according to Ankersmit, the paradigmatic third type of forgetting or trauma 1. As he states, in this type of trauma a painful lived experience is repressed with "the curious paradox that traumatic experience is both forgotten and remembered". ${ }^{14}$ In this type of forgetting, identity remains intact and can be re-established on the condition that this painful past is incorporated into a narrative that achieves a "reconciliation of experience and identity". ${ }^{15}$ According to his psychoanalytical point of view, the Holocaust, as a traumatic event, was repressed (forgotten) after the second world war. However, a "right story" can help re-establish that destroyed identity by the incorporation of this catastrophic past. Ankersmit states that this type of incorporation "could always be seen as changes in, and not of, our identi- 
ties", ${ }^{16}$ or, to put it metaphorically, "the building of new cities or highways are changes within the borders of our country, changes that leave these borders themselves unaffected".

Ankersmit also recognises other types of historical events that provoked what he calls a fourth type of forgetting, or trauma 2. The French revolution is an example of this type of event. Unlike events such as the Holocaust, this trauma 2 generates a definite break, representing the step from a previous identity towards one that is totally new and different. For Ankersmit, the French revolution creates an "insurmountable barrier" between a pre- and post-revolutionary world: "the world would have irrevocably and inexorably acquired "a new identity". ${ }^{17}$ The important difference between this type of trauma and trauma 1 is that the past is totally separated from the present in all aspects. Its characteristic of being "the other" is so strong that no story could have it as part of a same identity. This past becomes an object of historical research. According to Ankersmit, the conservatives, who "recognise that they are forever separated from the prerevolutionary past by the abyss between two different historical or cultural identities" could only have "a desire to know" that past. ${ }^{18}$ There is a total break: "We have been ejected, expelled, or exiled from the past; or, rather, because of some terrible event (such as the French Revolution) a world in which we used to live naively and unproblematically fell apart into a past and a present". ${ }^{19} \mathrm{In}$ Hobsbawm's terms, "A page in history has been turned." We "have been ejected from the past" in the sense that a former historical identity is "irrevocably lost forever" (the prerevolutionary world) and superseded by a new historical identity (the postrevolutionary world). If there is a possible reconciliation with trauma 1 , there is no possibility with trauma 2, because "the desire of knowledge (the past)" can never be satisfied by "the desire of being". The reactionaries to the revolution were not aware that the prerevolutionary world was gone forever and, for Ankersmit, they wanted to restore it. For reactionaries "the past is an object of the desire of being - they want to be(come) again what the past once was like". ${ }^{20}$ Ankersmit also exemplifies this break between past (a previous identity) and present (a new identity) with the Hegelian analysis of the conflict between Socrates and the Athenian state. Socrates' sentencing makes sense as far as it represents the end of the world of traditions of the Athenians, and the beginning of a moral world governed by universal principles. By condemning Socrates, the Athenian state was aware that a former time in which laws and customs were valid unconditionally, was gone forever.

Up to here I have dealt with Ankersmit. The question is: what is it that makes some events generate pasts which appear as different worlds while others do not? Why do some events, like the French revolution, and not others, like the Holocaust, produce such a break with the present that they generate pasts which can only be objects of knowledge and not objects of desire? How do those pasts, which historians can study without interfering with the moral, political and legal areas, which is not the case with the history of the present or the recent past, arise? Why could Hobsbawm state, just after it happened, that "very few people would deny that an epoch in world history ended with the collapse of the Soviet bloc and the Soviet Union, whatever we read into the events of 1989-91"?? When can we say that "A page in history has been turned"? Why would only a few people - or almost no one - say the same with regard to the Holocaust or the terrorism of the Latin American states? Why is the Argentinean Never Again normative? Never Again, as I understand it, is more an expression of desire than a confirmation of a rupture. In short, why do some events generate a bare historiography and not a history of the present? Or, 
to put it into the "presence paradigm" terms, why is it that some events generate an "absentpast" and not a "presence of the past"? 22

The most usual explanation has to do with the distance of the real historical events, at least from the theoretical and epistemological approach. This distance, understood in different ways, would produce more or less "objective" pasts, with almost no political or moral implications. Phillips, in a recently published book, ${ }^{23}$ admits that distance has little consideration in theory of history. His diagnosis is that the "silence" surrounding this topic shows evidence of implicit assumptions on the part of historians about our understanding of history. ${ }^{24} \mathrm{He}$ considers the field where historical representation meets memory as a good point to start his analysis. He mentions authors like Nora, Lowenthal and Novick, who establish a deep division between memory (which denies the relation between distance and the recent past) and history (which generates a sense of distance from its critical analysis). He considers this description too simplistic. (I also agree here.)

Phillips considers that the distance of the event is not only given, as for example in the Holocaust where two generations have already passed, but has also been constructed. ${ }^{25}$ Firstly, temporal distance could not be denied, it is always increasing and, according to how much later we are from the event, would involve higher or lower levels of objectivity in the reconstruction depending on the historian's and audience's interest in the event. "Distance, to put this another way, should refer to a dimension of our relation to the past." ${ }^{26}$ So, Phillips, recognises two types of distances. ${ }^{27}$ The historical representation makes use of a rhetorical distance that is related to all the strategies (textual or not) that allow one to "move away from" or "come closer to" its object. A dense description, i.e. a description replete with details, would emphatically bring the reader closer. This sort of description portrays experiences with more details. However, there would be different resources that, though connected to dramatic events, would make the cognitive access easier, building a distance that would prevent a moral or political identification. For Phillips, in the two cases described above, the constructive activity prevails on the historian's side, and it can generate the same distance effect as the one produced by time.

However, Phillips' studies fail to explain why an event like the fall of the Soviet world or the French revolution became past in such a way as to transform them into "the other". Neither the temporal proximity of one of them, nor the remoteness of the other, explains this. Consequently, the claim stating that historical distance is "constructed" by the historian (at least in these cases) becomes invalid. These types of events generate their own breaks without any mediation of retrospective temporal distances or distances constructed rhetorically by the historian. But how? Why does Ankersmit, for example, consider that "a right story" could reconstitute the identity between the painful Germany of the past and that of the present? Why is state terrorism still a possibility for some Argentineans? ${ }^{28}$

\section{II}

In modernity, past becomes the "old time" that must be left aside in order to have access to the "new time". In this way, "old time" experienced as an example, and with it history also experienced 
as example, is cancelled. History as magistra vitae falls when "'history itself'... [begins] to open up a new experiential space". The past cannot give any example and cannot provide any teaching either. Since the expression was coined by Cicero in De Oratore ${ }^{29}$ it lasted without interruptions until the eighteenth century. Whether the example that was taken from the past was used to defeat any generalisation or to find general rules, ${ }^{30}$ it has as an assumption the uniformity of human nature. Actually, if we do not assume or believe in the immutability of human nature, the past event being recalled loses its quality or usefulness as exemplum. ${ }^{31}$ This conviction in uniformity was shared by Voltaire and Hume, as well as by Montesquieu and Gibbon. In Hume, for example, the relation between this philosophical assumption and history appears in many passages of Treatise and Enquiry:

Would you know the sentiments, inclinations and course of life of the Greeks and Romans? Study well the temper and actions of the French and English: You cannot be much mistaken in transferring to the former most of the observations which you have made with regard to the latter. Mankind are so much the same, in all times and places, that history informs us of nothing new or strange in this particular. Its chief use is only to discover the constant and universal principles of human nature, by showing men in all varieties of circumstances and situations, and furnishing us with materials from which we may form our observations and become acquainted with the regular springs of human action and behaviour. ${ }^{32}$

However, the historia magistra vitae collapsed when the French revolution made it clear that no future is ever warranted and that experience is not enough to anticipate it. The new "nation-states" needed a past, "passéime", 33 an origin, an inscription in memory, to legitimise the incarnation of political, religious and military institutions in a space. In other words, the nation-states needed a past to which to resort as tradition and whose identity referred to the temporal landmarks which had to be commemorated. Before the American and French revolutions, memory used to separate more than unify. Only the aristocracy, church and monarchy had something similar to an "institutionalised" memory. Leaving the elites aside, which were responsible for the archives, genealogy and commemorations, ordinary people felt the past as part of their present, without the urgent need to recover or store it.

This started to change at the end of the eighteenth century, when the new nation-states needed people who had never met before or shared anything to consider themselves as sharing a "common history" ${ }^{34}$ Now the past, understood as a shared heritage, must be celebrated and commemorated, to assure a national identity that projects itself towards a better future: "A naïve confidence that the political upheaval meant regeneration and inaugurated a reign of justice and happiness pervaded France in the first period of the Revolution." ${ }^{35}$ This confidence overwhelmed people such as Condorcet, one of the most fervent theoreticians of progress, even when writing his Esquisse d'un tableau historique des progrès de l'esprit humain (1795) during Robespierre's terror.

According to Koselleck, modernity is misunderstood if the novelty that it introduces is interpreted only as a "new time" (neue Zeit) or a new order of time in which the modern concept of future and its correlate, progress, would have given birth to our concept of history. A very well-known par- 
agraph from Koselleck's Futures Past describes the rupture between "space of experience" (Erfahrungsraum) and "horizon of expectation" (Erwartungshorizont):

A consistent discovery in the following studies is the fact that the more a particular time is experienced as a new temporality, as "modernity", the more demands on the future increase. ${ }^{36}$... What was new about the expectation of the future that typified progress? ... The future of this progress is characterised by two main features: first, the increasing speed with which it approaches us, and second, its unknown quality. "Unknown" because this accelerated time, i.e., our history, abbreviated the space of experiences, robbed them of their constancy. ${ }^{37}$

This new order of historicity, which had an impact on the birth of historiography in the nineteenth century, cannot be understood, regardless of its political implication. The gap between past and the new beginning that these modern times establish ${ }^{38}$ is the result of a political rupture. Koselleck explains the rupture that the French Revolution caused as the result of a process ${ }^{39}$ that started in the sixteenth century with the failure of the empire and the birth of a new relation between religion and politics. "What consequences did the new arrangement of politics and religion have for the construction of the modern apprehension of time?"40 The religious wars weakened the belief in the Last Judgment prophecy in such a way that the Holy Roman empire began to lose its eschatological function. A new future, as a field of probabilities, appeared. The development of the present action depended now on the predictions made by politicians, bearing in mind the lesser evil. The prediction represents the temporal structure of absolutistic politics, which is a type of politics that predated the one developed at the end of the eighteenth century. It was a politics that "had not yet fundamentally ruptured the plane of Christian expectations". ${ }^{41}$ One of the characteristics of the prediction in the absolutist state is that it introduces the past in the future, since it is based on a calculation of probabilities. This new idea, which brought philosophies of history about the future through the concept of progress, accelerated time in such a way that no space of experience can be anticipated. This new idea started appearing before the French revolution. Koselleck never loses sight of the political reality of his temporal analysis: "The bearer of the modern philosophy of historical process was the citizen emancipated from absolutist subjectivation and the tutelage of the church: the prophète philosophe."42 The separation between past and present that modernity established is a political one, as it is well exemplified in a Malchus' quotation: "for in a state like ours, founded on victory, there is no past. It is a creation, in which - as in the creation of the universe everything that is present is but raw material in the hand of the creator by whom it is transformed into existence." 43 The analysis of the new order of time must not be carried out independently from the political action since "it is man's task to get to the golden future".

However, progressivism feeds on its own poison. In Lectures on the Philosophy of World History, published in 1830, Hegel writes

when we see the evil, the wickedness, and the downfall of the most flourishing empires the human spirit has created; and when we are moved to profound pity for the untold miseries of individual human beings ... Without rhetorical exaggeration, we need only compile an accurate account of the misfortunes which have over taken the finest manifestations of national and political life, and personal virtues of innocence, to see a most terrifying picture take shape before 
our eyes ... But even as we look upon history as an altar on which the happiness of nations, the wisdom of states and the virtue of individuals are slaughtered, our thoughts inevitably impel us to ask: to whom, or to what ultimate end have these monstrous sacrifices been made? ${ }^{44}$

The reality of the World Spirit, the final subject of history, depends on the actions, tendencies and institutions that represent reason and freedom. The law of history representing the World Spirit operates therefore above individuals and peoples. "The history is, then, understood, as the development of a history of right to freedom." ${ }^{45}$ Justice is realised through universal history. "History then appears as 'the slaughter bench' at which the happiness of peoples, the wisdom of states, and the virtue of individuals have been victimised." Hegel at the same time extols the sacrifice of individuals and the resulting general happiness. He calls it "the cunning of reason". "Individuals lead unhappy lives, they toil and perish, but though they actually never win their goal, their distress and defeat are the very means by which truth and freedom proceed." 46 In Philosophy of Law, Hegel declares that the rights of a state are subordinated to the rights of the World Spirit and to the trial of universal history. The history of a nation must be judged according to its contributions to the progress of all humankind towards free self-consciousness. What is considered catastrophic and unhappy from the individual's point of view becomes a slight accident, or rather a "ruse of reason", that governs from behind the order of things. Under the appearance of violence or barbarism, human passions reach their highest destiny. The triumphal entourage of history moves, hence, along with those who sow the ground, as Walter Benjamin writes. ${ }^{47}$

Modernity reversed its relation with antiquity when it began considering the latter as a child and not as a parent. Modernity understands human gender as an eternal subject that, with time, will achieve total control of its own destiny. Individuals die but their suffering helps to build the aim of humanity that, as well as being universal, is immortal. "However puzzling this may be, it is necessary if one assumes that a species of animals should have a reason, and, as a class of rational beings each of whom dies while the species is immortal, should develop their capacities to perfection. ${ }^{\prime \prime 8}$ From this progressive perspective, although the rights of communities may be taken away, those deplorable acts do not call into question the positive movement of the civilisation. Even when, legally or morally, humankind acts wrongly, historically humanity does not stop fulfilling its destiny.

\section{III}

This régime of historicity, ${ }^{49}$ the order of time mentioned above, has changed. The relation that the future established between humankind, individuals and their humanity, considering their generic and universal characteristics, is inverted, in a single movement, when one becomes conscious of the atrocities committed in the twentieth century. "Crimes against humanity" has become the legal definitions of these atrocities. Defined in the Nuremberg charter in 1945, ${ }^{50}$ ratified in Tokyo a year later, and declared "imprescriptible" by the United Nations and "imprescriptible by their nature" in French law in 1964, crimes against humanity represent the condemnation that "progress could no longer do without its victims", as Finkielkraut states. As Arendt writes, the judges, who defined human gender on the basis of its diversity and not its progress, and who became conscious that it is not the human being who lives on Earth but men and women in their endless diversity, spoke on behalf of the whole of international society since they believed that it was this society which had 
suffered irreparable damage "when one of its racial, national or cultural elements disappears". With the registration of human rights for humanity within a legal sphere, the self-realisation dogma of the human species in history was refuted. The "criminal enterprise against the human condition" that was created, according to Friedlander, "once a regime decides that groups, whatever the criteria may be, should be annihilated there and then and never be allowed to live on Earth", ${ }^{51}$ involved the discovery that humankind is not the instrument of a humanity that progresses in spite of the annihilation of groups.

The inversion of the relationship between particular (men and women) and universal humankind and the timelessness of the acts committed, redefines, among other things, the question of the historical experience of injustice. The interpretation of history in terms of an immanent justice becomes incoherent. Men and women are the ones who accept past wrongdoings and become responsible for those acts in the face of history. What is the result of attributing to oneself, in the present, the consequences of the actions that others committed in the past and for which now, among other things, forgiveness is being claimed? In other words, what does a "subversive" chang ${ }^{52}$ mean within the legal sphere if carried out in the same political order? It means taking responsibility for the future consequences of past actions and, in the imputation of the act, recognising the historical identity of those who committed the crime, and of those who were blamed. The retrospective movement of the assignment of responsibility establishes the subject's identity through time. We are in the inversion of modern temporality: the identity of the historical subject, the state, escapes to the past instead of the future..$^{53}$ This idea of the state as historical subject with a new orientation in time coexists with multiple subjects such as social or ethnic minorities. In this situation, the essential contingency of the post-revolutionary alliance between the state and the nation is revealed. ${ }^{54}$

This new order of time is not only expressed in this legal innovation but also in other issues. Firstly, the present historicises itself and, therefore, "histories of the present" or the recent past born in 1978, promoted by Bédarida, flourish. The events, which were lived or experienced by some members of generations that are contemporary to the historian are the new objects of history. Secondly, universal history disintegrates; "history crumbles", as Dosse so graphically describes. "We abandon significant periods in favour of the daily life of little people. A new esthetic topography takes over when we speak of villages, of women, of immigrants, of who are marginalised." ${ }^{\prime 55}$ Thirdly, on the other hand, historia magistra vitae appears again hidden behind Todorov's "exemplar memory", in spite of Koselleck's warning in 1973 about the uselessness of deducing learning from history. ${ }^{56}$ From a psychoanalytical approach, Todorov distinguishes a literal from an exemplary memory and makes a distinction with his critics about the uses of memory. A group's past painful event "is preserved in its litéralité; it remains single, impassable, it does not lead beyond itself". ${ }^{77}$ Hence, a relation of proximity between the group's past and present is established, extending the consequences of the initial trauma to all the moments of existence. The other form of recollection, the exemplary, is characterised by recovering the past nature of the event, and, without leaving aside its singularity, transforming it into the model to follow in the present when confronted by new situations. Memory becomes an exemplum and a "principle of action" for the present. The future stubbornness reopens the old topoi of history understood as magistra vitae, which one of its assumptions, as Kosel- 
leck points out, is the uniformity of human nature. The past as an example can only be considered when continuity with the present is identified, and therefore the "duty to remember" makes sense.

\section{IV}

I have now addressed how the orders of time are connected. In this section, I will provide an analysis. As terrible or unmentionable as the twentieth-century genocides were - Hobsbawm called them "catastrophes" - they were not able to disrupt the political structures from which they arose. Although they changed the orders of time by establishing a new temporal regime with the concept of "crimes against humanity", they did so by preserving the political world in which they originated. Present institutions completely identify with their past selves. I believe that the Argentina of today, for instance, is "better" than the Argentina that existed under a dictatorial government; the Germany of today is "better" than the Weimar republic. It is possible to perform a qualitative assessment only when identification is acknowledged. Such identities reside in the structure of the modern nationstate in whose framework Latin American state terrorism and the Holocaust were possible and through which the conditions are preserved that make it possible for these events to continue to occur. To deny this is to deny the "disappearance" of Jorge Julio López in $2006,{ }^{58}$ the coup d'état in Honduras in 2009, and the mass killing of thousands of civilians carried out by "democratic states" in the name of human rights. This temporal continuity makes it understandable, for example, that a president could apologise publicly for atrocities that he did not commit. This is a historical peculiarity of the twentieth century. ${ }^{59}$ Because the present is understood in terms of the past, the "duty to remember" is imperative; ${ }^{60}$ we must remember if we are to avoid repeating our mistakes. This imperative will remain in force until a new political world is established whose structure makes it impossible for such atrocities to be repeated.

"All beginnings contain an element of recollection." For Connerton, ${ }^{61}$ the element of memory is particularly necessary when a group is struggling to establish a new regime. Within the sequence of a temporal experience, a new beginning threatens to abolish temporal continuity. Conscious of this new beginning, a group typically establishes a yearly holiday to memorialise and preserve the rupture. For Connerton, the trial and execution of Louis XVI clearly demonstrate an intention to establish a new social order: "the trial by fiat of a successor regime is like the construction of a wall."62 This barrier is built to avoid future transgressions. The trial and execution of Louis XVI were not merely the assassination of a monarch, but the revocation of a legislative principle: the agreement that a dynasty was the only possible political system. The execution represented part of a process of rupture with the ancien régime. Later named the French Revolution, July 14 was established as a day to commemorate this event. ${ }^{63}$ Connerton clearly describes the problems encountered by "new" regimes. For example, problems arise when some forms of property confiscation used by the old regime become, within the new regime, "punishable" and unfair. This situation raises the following question: what obligations do those who were the executors of past injustices have towards their former victims in the new regime? Connerton asks: "How far must one go when taking into account the memory of past injustice, in wiping clean the historical record of illegitimate acts?" He answers ambiguously when he builds a barrier between the new beginning and the old tyranny, a barrier that ultimately recollects the old tyranny. ${ }^{64}$ Remembering the past allows a better regime to be realised. However, creating obligations to compensate past injustices would not be beneficial 
under the new laws, which prevent these injustices from being repeated. The collapse of the Soviet world, for example, marked a political rupture from the regime that had begun with the Russian revolution. As a modern revolution, the Russian Revolution had expressed the modern promise of progress; the fall of the Berlin Wall signalled its end. Who should be held responsible for the reparation of Soviet atrocities? Once the USSR disappeared as a political entity, no political subject could assume the responsibility and financially compensate the "past victims". It is possible to establish a "truth commission" to determine historical truth, but no financial compensation can be granted. "Transitional justice" becomes meaningless in the contexts of the American, French and Russian revolutions, which are conceived as revolutions meant to disrupt the political order. Consequently, Connerton is mistaken when he equates the trial and execution of Louis XVI with the Nuremberg trials, in which "crimes against humanity" were punished.

The legal concept of "crimes against humanity" is incredibly "enlightened". Such crimes could not be conceived of or understood without a shared belief in the uniform identity of "humankind". Those who declare that crimes against humanity are timeless, "imprescriptible by their nature", punish a future that shares the same political order as the present order in which such crimes are allowed to occur. This concept is extremely pessimistic about future generations. It assumes that future generations will not be capable of generating another political order (a "new" regime) in which the atrocities committed under the modern political order would become unthinkable. Thus, crimes against humanity, as legal objects, are corrupted by the principle of universalism because they can forever punish the same crime. Nora poignantly expresses this idea in the conclusion of his analysis of the obsession with commemorations. Speaking of the French case, he says: "Today's options make sense only for this present moment when French people have a different collective lifestyle and when they feel comfortable within a framework that cannot even be called identity, and therefore the need to exhume past marks and explore the places will disappear. The era of commemoration will definitely be left behind: 'The tyranny of memory will have lasted only a moment'."'65 Perchance, in the future, another world will exist in which people have a different collective lifestyle, perhaps so different that historiography, as we know it today, will be useless. 


\section{NOTES}

* I would especially like to thank Hayden White for the time invested in discussions that in so many ways have shaped and improved this article. I also want to thank Nora Rabotnikof for her thoughtful suggestions to the first draft of the manuscript.

1 “I only pray to God/that the future isn't indifferent to me." From the lyrics of León Gieco, a contemporary musician, writer and performer from Argentina whose songs are full of political and social connotations.

2 Jay M. Winter, Remembering War: The Great War between Memory and History in the Twentieth Century, New Haven and London: Yale University Press, 2006. Quoted in Eelco Runia, "Burying the dead, creating the past", History and Theory 46/3 (2007): 313-325.

3 Charles S. Maier, "A surfeit of memory? Reflections with history, melancholy and denial", History and Memory 5/2 (1993): 136-152.

4 Andreas Huyssen, “Present pasts: media, politics, amnesia”, Public Culture 12/1 (2000): 21-38, 25. Huyssen borrows the term from Hermann Lübbe, Zeit-Verhältnisse: Zur Kulturphilosophie des Fortschritts, Graz: Styria, 1983.

5 Runia, "Burying the dead," 46.

6 Huyssen "Present pasts," 21.

7 See note 14.

8 Frank Ankersmit, Sublime Historical Experience, Stanford: Stanford University Press, 2005.

9 Berber Bevernage, “Time, presence and historical injustice”, History and Theory 47/2 (2008): 149-167.

10 Pierre Nora, Les Lieux des mémoires, Paris: Gallimard, 1998, 13.

11 Eric Hobsbawm uses the term catastrophe to designate one of the periods of the Age of Extremes. This age is further subdivided into "The Age of Catastrophe" (1914-50), "The Golden Age" (1950-75) and "The Landslide" (1975 to 1991 and beyond) in Eric Hobsbawm, Age of Extremes: The Short Twentieth Century, 1914-1991. London: Michael Joseph, 1994. See also John Torpey, who speaks about an increasing "consciousness of man-made catastrophe", in Making Whole What Has Been Smashed: On Reparation Politics, Cambridge: Harvard University Press, 2006, 32. I would like to thank Prof Berber Bevernage for informing me about this latter book.

12 Dominick LaCapra, Representing the Holocaust: History, Theory and Trauma, New York: Cornell University Press, 1994; Idem, Writing History, Writing Trauma, Baltimore: Johns Hopkins University Press; Cathy Caruth, Unclaimed Experience: Trauma, Narrative and History, Baltimore: Johns Hopkins University Press, 1996; Leigh Gilmore, The Limits of Autobiography: Trauma and Testimony, Ithaca: Cornell University Press, 2001; Arthur Neal, National Trauma and Collective Memory: Major Events in the American Century, New York: ME Sharpe, 1998; Nebojsa Popov, The Road to War in Serbia: Trauma and Catharsis, Budapest: Central European University Press, 1999; Dan Bar-On, The Indescribable and Undiscussable: Reconstructing Human Discourse After Trauma, Budapest: Central European University Press, 1999; Ruth Leys, Trauma: A Genealogy, Chicago: University of Chicago Press, 2000; Gavin Langmuir, History, Religion and Antisemitism, Berkeley: University of California Press, 1990; Ankersmit, Sublime Historical Experience; Runia, "Burying the dead", and so on. In this vast literature on the relationship between trauma and history, two types of approaches can be distinguished: the speculative and the empirical. The speculative approach to history as trauma is a theoretical model that understands the historical process - history as res gestae - as the return of the historically repressed. The concept 
of trauma is constructed in code to interpret the sense of history in the same manner that Marx understood class struggles or that Hegel perceived spirit development. Several of Freud's writings such as Group Psychology and Analysis of the Ego (1921), Moses and Monotheism (1939) or Totem and Taboo (1912-1913), which support these arguments, invalidate the break between individual and collective psychology. However, even though Freud had doubts about the value of his sociohistoric investigations, some historians have extended their analytical apparatus to describe collective phenomena, such as Caruth, Unclaimed Experience, or Langmuir, History, Religion and Antisemitism, for example, who go beyond their analytical apparatus to collective phenomena. Thus, the western secularisation process is interpreted as one that involved a conflict among the emergent forces - such as science, rational ways of economic production, bureaucratic behaviour, etc - and primitive religious practises and beliefs. As the rupture with this symbolic world was traumatic, "there would be a tendency of the repressed side to take up again under distorting ways, specially under a movement like the Nazism that ... claims simultaneously its pagan force and its inclusion in the popular Christian Anti-Semitism". LaCapra, Representing the Holocaust, 188. Trauma becomes a condition of historical possibility. An empirical approach to trauma in history can be opposed to the previous description of history as trauma. In historical analyses that consider specific historical phenomena in our recent past, the concept of trauma represents a category of analysis that provides heuristic value. From this point of view, modern social phenomena are characterised as traumatic, which makes theoretical perspectives and psychoanalytical techniques relevant to historiography. However, the temporality of trauma is incompatible with the temporality of history. Cf. María Inés Mudrovcic, "Alcances y límites de perspectivas psicoanalíticas en historia”, Diánoia 48/50 (2003): 111-127.

13 Ankersmit, Sublime Historical Experience, 321-327.

14 Ibid, 322.

15 Ibid, 328.

16 Ibid, 2005, 330.

17 Ibid, 326. Unlike Ankersmit, Runia equals events such as the French revolution and the Holocaust, which he calls "impossible acts" in which "we leave the beaten track and embark upon the unknown as we did in events like the American Declaration of Independence, the French Revolution, the secession of the Confederation of the South, Bismark's unification of Germany, the First World War, the Holocaust, and the redrawing of the map of what used to be Yugoslavia". Runia, "Burying the dead", 318.

18 Ankersmit, Sublime Historical Experience, 327.

19 Ibid, 327-8.

$20 \quad$ Ibid, 327.

21 Eric Hobsbawm, "The present as history", in idem, On history, New York: The New Press, 1997, 235. This same feeling of having abandoned a world is expressed by Edmund Burke, a fierce critic of the French revolution, only a year after the fall of the Bastille: "It appears to me as if I were in a great crisis, not of the affairs of France alone, but of all Europe, perhaps of more than Europe. All circumstances taken together, the French Revolution is the most astonishing that has hitherto happened in the world" in Edmund Burke, Reflections on the Revolution in France (1790), ed. A.J. Grieve, London: Dent, 1950, 8.

22 Bevernage, "Time, presence and historical injustice", 47.

23 Mark Salber Phillips, "History, memory and historical distance”, in Peter Seixas (ed), Theorizing Historical Consciousness, Toronto: University of Toronto Press, 2004, 88-102.

$24 \quad$ Ibid, 87 
Ibid, 92: "Every history - indeed every representation of the past - has to engage with the problem of positioning its audience in relations of proximity or detachment to the events and experiences represented."

$26 \quad$ Ibid, 96.

27 In 2011, the theme issue of History and Theory (50/4) was focused on discussing the concept of "historical distance". Until then, the concept was treated uncritically by philosophers such as Gadamer and historians like Collingwood. However, in early 2011, Hayden White wrote to me in an email that the concept of "temporal distance was a contradiction in terms".

28 If it were not possible, it would not have been used as a rhetorical strategy in political fights in Argentina.

29 Taken from Reinhart Koselleck, Futures Past: On the Semantics of Historical Times, New York: Columbia University Press, 1985, 23.

$30 \quad$ Ibid, 22.

31 There is a difference between exemplary history (mythical) and historia magistra vitae. In traditional societies, the "exemplary event" must be understood as a "pattern" that must be repeated, if possible, with no modifications. In the topoi historia magistra vitae, the past event provides an "illustrative case" of a rule or exception.

32 David Hume, Enquiries Concerning the Human Understanding and the Principles of Morals, Oxford: Clarendon Press, 1961, 84. The relation that Hume establishes between the uniformity principle of human nature and history is not exempt from circularity. As a moral and political philosopher, Hume uses history as a datum to formulate general principles of human nature. As a historian, Hume uses the generalisations that he formulated from history to judge the probability of an event or the truth of a testimony.

33 Nora, Les Lieux des mémoires, 561.

34 John R. Gillis, "Introduction. Memory and identity: the history of a relationship", in idem, Commemorations: The Politics of National Identity, New Jersey: Princeton University Press, 1994, 6-7.

35 John Bagnell Bury, The Idea of Progress: An Inquiry Into its Origin and Growth, New York: Dover Publications, 1932, 204-205.

36 Koselleck, Futures Past, xxiv.

$37 \quad$ Ibid, 17.

38 Rupture is also acknowledged by Ankersmit and Hobsbawm in the Soviet case.

39 Ruptures should not be interpreted as sudden discontinuities.

40 Koselleck, Futures Past, 9.

41 Ibid, 16.

42 Ibid, 17

43 Ibid, 35

44 Georg Wilhelm Friedrich Hegel, Lectures on the Philosophy of World History, trans. Hugh Barr Nisbet; intro. Duncan Forbes, Cambridge: Cambridge University Press, 1975, 68-69.

45 Reinhart Koselleck, “Histoire, droit et justice”, in idem, L'experience de l'histoire, Paris: Gallimard, 1997, 
170. Koselleck relates historical experience to justice and attempts to determine the types of justice that historians narrate in their accounts of history (164). He recognises five types of justice, two of which are typically modern: "history as an absurd" and "history as court of justice" represented by Hegel.

46 Herbert Marcuse, Reason and Revolution: Hegel and the Rise of Social Theory, New York: Humanities Press, 1963, 233.

47 Walter Benjamin, "Theses on the philosophy of history", in idem, Illuminations, London: Fontana Press. 1992, 245-256.

48 "Third thesis", in Immanuel Kant, On History, Indianapolis: Bobbs-Merril, 1963. 14.

49 To use a concept coined by the French historian François Hartog. See Régimes d'historicité: Présentisme et expériences du temps, Paris: Seuil, 2003.

50 Article 6 (c) of the 1945 London Charter of the International Military Tribunal (Nuremberg Charter) states: "murder, extermination, enslavement, deportation, and other inhumane acts committed against civilian populations, before or during the war; or persecution on political, racial or religious grounds in execution of or in connection with any crime within the jurisdiction of the Tribunal, whether or not in violation of the domestic law of the country where perpetrated".

51 Saul Friedlander, Memory, History, and the Extermination of the Jews of Europe, Bloomington: Indiana University Press, 1993, 82-83.

52 I have chosen the word "subversive" on purpose because of its connotation for our Argentinean recent past, but I also refer to the Merriam Webster Dictionary: to subvert is to overturn or overthrow from the foundation; to pervert or corrupt by an undermining of morals, allegiance, or faith.

53 On 15 March 2000, the International Council of Christians and Jews issued a press release that acknowledged the "historical step" that was carried out by Pope John Paul II after he admitted the Catholic church's culpability for past crimes against different groups and communities. In the press release, the association also regretted the church's apparent difficulty admitting responsibility and historical guilt: "not only those Catholics in general but also those responsible for leading the church through centuries must be included". On 17 January 2001, a historical compensation treaty was signed in Washington DC, which warranted rapid payment to Austrian victims of Nazi persecution. Ernst Sucharipa, the Austrian ambassador, suggested that the treaty "represents a great contribution on part of the Austrian state by giving an answer to the terrible fact that was Nazism". On July 10 of the same year, the Polish president publicly apologised for the 1941 mass killing of 1,600 Jews in Jedwabne. These crimes were not carried out by Nazi soldiers alone but by the entire Jedwabne community. Rather, the community was incited by soldiers, as was described in Polish historian Jan Tomasz Gross's book (The Neighbors: The Destruction of the Jewish Community in Jedwabne, Poland, Princeton: Princeton University Press, 2001). In Peru, article 2 of the supreme decree creating the Truth and Reconciliation Commission, passed by the Council of Ministers in 2001, seeks to "draw up proposals for reparation and dignification of the victims and their family members." See www.mississippitruth.org/documents/PERU.pdf (acessed 7 Jun 2014)

54 See Elias Palti, La nación como problema: Los historiadores y la "cuestión nacional”, Buenos Aires: FCE, 2003.

55 François Dosse, New History in France: The Triumph of the Annales, trans. Peter V. Conroy. Chicago: University of Illinois Press, 1994, 2

56 Reinhart Koselleck, "Vorwort”, in idem, Kritik und Krise: Eine Studie zur Pathogenese der bürgerlichen Welt, Frankfurt am Main: Suhrkamp, 1973, 1-9. 
57 Tzvetan Todorov, Les abus de la mémoire, Paris: Arléa, 2004, 31.

58 Jorge Julio López was an ex-activist and member of the Socialist Party in La Plata, Argentina. He was kidnapped and imprisoned from 1976 to 1979 during the military dictatorship. He ultimately “disappeared" in 2006 while Nestor Kirchner was in power. The trial of Miguel Etchecolatz was taking place at the time, and Julio Lopez was a key witness.

59 Corroborating this, Torpey says, "The proliferations of demands that states, churches and private firms be compelled to pay 'reparations' to those whom they are said to have wronged in the past, or at least pressured to apologise for such wrongdoing, represents one of the more striking developments in recent affairs." John Torpey, Making Whole What has Smashed, Harvard: Harvard University Press, 2006, 8.

60 Political subjects (the states) can apologise, make compensation through economic retribution, and create courts of truth guided by the past futures that did and did not occur (like those of the oppressed). Today, these courts create an institutionally recognised "victim of the past". In Argentina, a law was recently passed mandating that all persons held as political prisoners between 1955 and 1976 will be compensated financially.

61 Paul Connerton, How Societies Remember, Cambridge: Cambridge University Press, 1989, 6.

62 Ibid, 7.

63 Mona Ozouf, Festivals and the French Revolution, Cambridge: Harvard University Press, 1994, 8. Cited in Gillis, Commemorations, 8.

64 Connerton, How Societies Remember, 9-10: "What kind of criminal blame and what obligations do the performers of past injustice have towards those whose position is worse than it would have been had the injustice not been perpetrated?"

65 Nora, Les Lieux, 637. My translation. 